\title{
Chilling injury in stored nectarines and its detection by time-resolved reflectance spectroscopy
}

\author{
S. Lurie ${ }^{\mathrm{a}, *}$, M. Vanoli ${ }^{\mathrm{b}, \mathrm{c}}$, A. Dagar ${ }^{\mathrm{a}, \mathrm{d}}$, A. Weksler ${ }^{\mathrm{a}}$, F. Lovati ${ }^{\mathrm{b}}$, P. Eccher Zerbini ${ }^{\mathrm{e}}$, L. Spinelli ${ }^{\mathrm{f}}$, A. Torricelli $^{\mathrm{c}}$, \\ J. Feng ${ }^{g}$, A. Rizzolo ${ }^{b}$ \\ a Department of Postharvest Science, Agricultural Research Organization, Bet Dagan, Israel \\ ${ }^{\mathrm{b}}$ CRA-IAA, Consiglio per la Ricerca e la Sperimentazione in Agricoltura, Unità di Ricerca per i Processi dell'Industria Agroalimentare, Milan, Italy \\ ' CNR-IFN, Politecnico di Milano, Dipartimento di Fisica, Milan, Italy

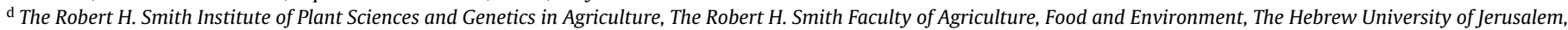 \\ Rehovot 76100, Israel \\ e Horticultural Supply Chains, Wageningen University, The Netherlands \\ ${ }^{\mathrm{f}}$ Istituto di Fotonica e Nanotecnologie, CNR, Milan, Italy \\ g Plant E' Food Institute, Auckland, New Zealand
}

\section{A R T I C L E I N F O}

\section{Article history:}

Received 27 April 2010

Accepted 24 October 2010

\section{Keywords:}

Prunus persica

Gel breakdown

Bleeding

Internal browning

Nondestructive measurement

Mealiness

Woolliness

\begin{abstract}
A B S T R A C T
Nectarine fruit after cold storage soften normally, but become dry instead of juicy and can develop flesh browning, bleeding and a gel-like or glassy formation of the flesh near the pit. An experiment was conducted to see if time-resolved reflectance spectroscopy could distinguish these internal disorders non-destructively. The optical parameters of absorption coefficient $\left(\mu_{\mathrm{a}}\right)$ and reduced scattering coefficient $\left(\mu_{s}^{\prime}\right)$ were measured at $670 \mathrm{~nm}$ and $780 \mathrm{~nm}$, on nectarine (Prunus persica cv. Morsiani 90) fruit held at $20^{\circ} \mathrm{C}$ after harvest or after $30 \mathrm{~d}$ of storage at $0^{\circ} \mathrm{C}$ or $4{ }^{\circ} \mathrm{C}$. Each day for $5 \mathrm{~d} 30$ fruit were examined both non-destructively and destructively. Other measurements were firmness with a penetrometer, peel colour on the blush and non-blush side, expressible juice, weight loss, and visual rating of internal browning, bleeding, and gel. The fruit had been sorted at harvest according to the value of $\mu_{\mathrm{a}} 670$ so that each batch had a similar spread of fruit maturity. More mature fruit (lower $\mu_{\mathrm{a}} 670$ values) developed internal browning and bleeding with more severe symptoms compared to less mature ones (higher $\mu_{\mathrm{a}} 670$ values). It was found that $\mu_{\mathrm{a}} 780$ could distinguish healthy fruits from the chilling injured ones. Canonical discriminant analysis indicated that fruit without cold storage had low $\mu_{\mathrm{a}} 780$, less water loss, low firmness, but high $\mu_{\mathrm{a}} 670$ and high expressible juice compared with cool stored fruit. Fruit cool stored at $4^{\circ} \mathrm{C}$ had high $\mu_{\mathrm{a}} 780$ and less expressible juice, lower water loss and lower firmness compared with fruit cool stored at $0{ }^{\circ} \mathrm{C}$. It was concluded that time resolved reflectance spectroscopy could detect internal woolliness and internal browning in nectarines after storage.
\end{abstract}

(C) 2010 Elsevier B.V. All rights reserved.

\section{Introduction}

Peaches and nectarines ripen and deteriorate quickly at ambient temperature. Cold storage is used to slow these processes and decay development. However, low temperature disorders, chilling injury $(\mathrm{CI})$ classified as internal breakdown, limit the storage life of peaches and nectarines under refrigeration. The onset of chilling injury symptoms determines the postharvest storage/shipping potential because their development reduces consumer acceptance. $\mathrm{Cl}$ is genetically influenced and triggered by a combination of storage temperature and storage period (Crisosto et al., 1999; Peace et al., 2004). It manifests itself as fruit that are dry and have

\footnotetext{
* Corresponding author. Tel.: +9723 9683606; fax: +97239683622.

E-mail address: slurie43@agri.gov.il (S. Lurie).
}

a mealy or woolly texture (woolliness), or hard textured fruit with no juice (leatheriness), fruit with flesh browning (internal browning), or with flesh bleeding (internal reddening) (Lurie and Crisosto, 2005).

It has been widely reported that the expression of CI symptoms, especially flesh browning and woolliness, develops faster and more intensely when susceptible fruit are stored at temperatures between 2.2 and $7.6^{\circ} \mathrm{C}$ (killing temperature zone) than those stored at $0^{\circ} \mathrm{C}$ (Harding and Haller, 1934; Crisosto et al., 1999). These symptoms mainly develop during fruit ripening after cold storage, and the problem is not noticed until the fruit reaches customers (Bruhn et al., 1991; Crisosto et al., 1995). Since the problem develops following storage, it would be advantageous if there was a way to determine $\mathrm{CI}$, so as to remove the affected fruit from the marketing chain and increase consumer satisfaction, and return purchases. 
Time-resolved reflectance spectroscopy (TRS) is a nondestructive technique based on the measurement of the temporal delay and broadening experienced by a short laser pulse (pulse duration in the order of $100 \mathrm{ps}$ ) while travelling through a turbid medium, such as fruit flesh (Torricelli et al., 2008). By using an appropriate theoretical model of light penetration for the analysis of photon time distribution, it is possible to simultaneously estimate the absorption coefficient $\left(\mu_{\mathrm{a}}\right)$ and the reduced scattering coefficient $\left(\mu_{\mathrm{s}}^{\prime}\right)$. The absorption and reduced scattering coefficients correspond, respectively, to the probability (per unit distance travelled by a photon) of being absorbed by the main fruit components (water, chlorophyll, carotenoids and sugars) and of changing direction due to microscopic changes in refractive index caused by membranes, air, vacuoles, or organelles. TRS probes fruit and vegetable to a depth as great as $1-2 \mathrm{~cm}$, depending on the optical properties (Cubeddu et al., 2001).

It was found that the absorption coefficient at $670 \mathrm{~nm}\left(\mu_{\mathrm{a}} 670\right)$, the absorption peak of chlorophyll-a, is linked to fruit biological age, and decreases as fruit ripen (Tijskens et al., 2006). In nectarines the conversion of $\mu_{\mathrm{a}} 670$ to a biological shift factor was successfully used to predict fruit softening rate during shelf life (Eccher Zerbini et al., 2006; Tijskens et al., 2007), allowing the selection of fruit for different market destinations (Eccher Zerbini et al., 2009). By using $\mu_{\mathrm{a}} 670$, it was possible to select nectarines having distinctive sugar, acid and aroma compositions, as well as sensory characteristics (Jacob et al., 2006; Bianchi et al., 2004; Eccher Zerbini et al., 2003). Furthermore, in apples a relationship was observed between optical properties, mainly the scattering coefficient, and the 'mealy' sensory attribute. In fact, mealiness increased with increasing scattering coefficient measured at $780 \mathrm{~nm}\left(\mu^{\prime}{ }_{s} 780\right)$ in 'Jonagored' apples (Vanoli et al., 2007), and increasing scattering coefficient measured at $790 \mathrm{~nm}$ and $912 \mathrm{~nm}\left(\mu_{\mathrm{s}}^{\prime} 790\right.$ and $\mu_{s}^{\prime} 912$ ) and decreasing absorption coefficient measured at $912 \mathrm{~nm}$ ( $\left.\mu_{\mathrm{a}} 912\right)$ in 'Braeburn' apples (Vanoli et al., 2010). In addition, in Granny Smith apples the absorption coefficient measured at $750 \mathrm{~nm}\left(\mu_{\mathrm{a}} 750\right)$ was higher in fruit having internal browning compared to the healthy fruit (Vanoli et al., 2010).

In the present study, the optical parameters of absorption coefficient $\left(\mu_{\mathrm{a}}\right)$ and reduced scattering coefficient $\left(\mu_{\mathrm{s}}^{\prime}\right)$ measured at $670 \mathrm{~nm}$ and $780 \mathrm{~nm}$, by TRS were used to detect chilling injuries in stored nectarines.

\section{Materials and methods}

\subsection{Plant material and storage}

Nectarines (Prunus persica cv. Marsiani 90) were harvested on 13 September 2009 in a commercial orchard in Faenza (Italy) and 480 fruit without defects and bruises were selected. At harvest, each fruit was measured on two sides by TRS using a prototype built at Politecnico di Milano (Torricelli et al., 2008) and ranked by decreasing absorption coefficient at $670 \mathrm{~nm}\left(\mu_{\mathrm{a}} 670\right)$ averaged over the two fruit sides, i.e. from less mature to more mature fruit (Eccher Zerbini et al. 2006; Tijskens et al., 2007). Ranked fruit were grouped into 16 sets of 30 fruit, corresponding to 30 levels of $\mu_{\mathrm{a}}$ (10 less mature class, 10 medium mature class and 10 more mature class). Then each fruit within each set was randomly assigned to a different group (i.e. time of analysis) in order to have fruit from the whole range of $\mu_{\mathrm{a}}$ at every time of analysis. One group was analyzed at harvest, while the other 15 groups were assigned for analysis during shelf-life at $20^{\circ} \mathrm{C}$. There were three treatments, each with 5 times of analysis (groups): five groups were put in shelf life at $20^{\circ} \mathrm{C}$ $(\mathrm{RH} \approx 78 \%)$ at harvest without any storage and analyzed after 1,2 , 3,6 and $7 \mathrm{~d}$; five groups were stored at $4{ }^{\circ} \mathrm{C}(\mathrm{RH} \approx 90 \%)$ for 4 weeks, and then put in shelf life at $20^{\circ} \mathrm{C}$ and analyzed at day $1,2,3,4$ and
5; the other 5 groups were placed into $0{ }^{\circ} \mathrm{C}(\mathrm{RH} \approx 70 \%)$ storage for 4 weeks and then analyzed during shelf life at $20^{\circ} \mathrm{C}$ after $1,2,3,4$ and $5 \mathrm{~d}$. During shelf life fruit were kept in a controlled temperature room at $20^{\circ} \mathrm{C}$.

\subsection{Measurements}

At harvest all the fruit were individually measured for the following parameters: absorption and reduced scattering coefficients at 670 and $780 \mathrm{~nm}\left(\mu_{\mathrm{a}} 670, \mu_{\mathrm{a}} 780, \mu_{\mathrm{s}}^{\prime} 670 \mathrm{and} \mu_{\mathrm{s}}^{\prime} 780\right)$, weight, peel colour on the blush and opposite side at two scales, $L^{*}, a^{*}, b^{*}$ and $L^{*}$, $C^{*}, H^{\circ}$ using a spectrophotometer CM-2600d (Minolta Co., Japan). These parameters were measured again at each time of analysis during shelf life. Weight loss was calculated from the initial and final weight. Firmness on blush and non-blush side was determined with an $8 \mathrm{~mm}$ diameter plunger mounted on a Texture Analyzer TA.Xtplus (Stable Micro Systems, England), with crosshead speed of $200 \mathrm{~mm} / \mathrm{min}$, on the two peeled cheeks of each fruit, in positions corresponding to the two TRS readings. A plug was removed from each fruit and a $1 \mathrm{~cm}$ section just below the peel was taken for determination of expressible juice by the method of Lill and van der Mespel (1988). Each fruit was then halved and examined visually for chilling injuries (gel formation, internal browning and internal reddening). The disorders were rated on a scale of $1-3$, with 1 healthy and 3 when all the flesh was affected. For each disorder a severity index was computed by multiplying the number of fruit in each score class by the score of the class and dividing their sum by the maximum possible score (as if all fruit had score 3). In addition, within the same sample (time of analysis), the fruits belonging to the same TRS maturity class (less mature, medium mature and more mature) were calculated for the chilling injuries. Furthermore stored fruit were separated according to pulp defects into the following seven categories, irregardless of storage temperature and day of shelf-life; healthy $(\mathrm{H})$, only browning (BR), only gel $(G)$, only bleeding $(B L)$, browning associated to gel $(B R+G)$, bleeding associated to browning $(\mathrm{BL}+\mathrm{BR})$ and bleeding associated to both browning and gel $(B L+B R+G)$.

\subsection{Statistics}

Firmness, weight loss, expressible juice, optical properties and colour parameters were submitted to analysis of variance (ANOVA) considering as factors the day of shelf life and the treatment (GLM procedure, SAS Version 9.1, SAS Institute Inc., USA). Means were compared by Tukey's test at $p<0.05 \%$.

In order to study the relationships among the optical properties and the presence of bleeding, browning and gel, the data variables of the optical properties measured in shelf life after storage at $0{ }^{\circ} \mathrm{C}$ and $4{ }^{\circ} \mathrm{C}\left(\mu_{a} 670, \mu_{\mathrm{a}} 780, \mu^{\prime}{ }_{s} 670\right.$ and $\left.\mu^{\prime}{ }_{\mathrm{s}} 780\right)$ and the scores of each fruit regarding bleeding, browning and gel were submitted to principal component analysis (PCA, Statgraphics, version 7, Manugistic, Inc., Rockville, MD). The PC1 and PC2 scores were then submitted to analysis of variance (ANOVA) and means were compared by 95.0 percent Bonferroni method considering as factors the categories of pulp defects. Correlation analysis between $\mu_{\mathrm{a}} 670, \mu_{\mathrm{a}} 780, \mu_{\mathrm{s}}{ }_{\mathrm{s}} 670$ and $\mu_{s}^{\prime} 780$ and expressible juice was carried out considering separately the data of each treatment $(n=150)$.

Stepwise canonical discriminant analysis was used to select fruit attributes that made a significant contribution to discrimination of fruit into different treatments. In this case, only data from the last two days of shelf life (fruit without storage assessed on shelf days 6 and $7,0^{\circ} \mathrm{C}$ and $4{ }^{\circ} \mathrm{C}$ fruit assessed after 4 and $5 \mathrm{~d}$ shelf life) were used. There were 17 input variables ( $\mu_{\mathrm{a}} 670$ and $\mu_{\mathrm{a}} 780, \mu^{\prime}{ }_{\mathrm{s}} 670$ and $\mu_{\mathrm{s}}^{\prime} 780$, weight loss, $L^{*}, a^{*}, b^{*}, C^{*}$, hue for both background and blush side of the fruit, firmness and expressible juice) used for stepwise canonical discriminant analysis and only seven selected variables 


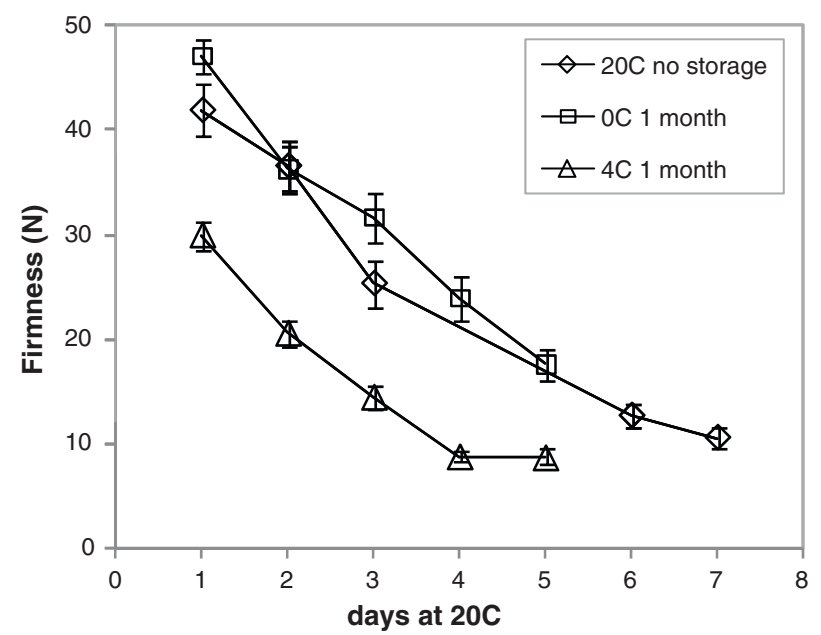

Fig. 1. Firmness of nectarines held at $20^{\circ} \mathrm{C}$ without storage, or following $30 \mathrm{~d}$ storage at $4{ }^{\circ} \mathrm{C}$ or $0^{\circ} \mathrm{C}$. Standard error is indicated.

were used for Canonical discriminant analysis (Cruz-Castillo et al., 1994). Canonical discriminant analysis was undertaken using the software package SAS Version 9.1 (SAS Institute Inc., USA).

\section{Results}

\subsection{Fruit softening and peel colour}

The fruits lost firmness during the shelf life period at $20^{\circ} \mathrm{C}$ (Fig. 1). Fruits stored at $0{ }^{\circ} \mathrm{C}$ were of the same firmness as at harvest when removed from storage, but softened over the $5 \mathrm{~d}$ period at $20^{\circ} \mathrm{C}$ to a similar extent as non-stored fruit. During $4{ }^{\circ} \mathrm{C}$ storage there was $40 \%$ loss of firmness (from $52 \pm 12 \mathrm{~N}$ to $30 \pm 7 \mathrm{~N}$ ) and the fruit advanced in ripeness, but continued to soften once removed. The trend of fruit softening was similar in all three treatments, although the final firmness of fruit from $4{ }^{\circ} \mathrm{C}$ storage was lower than that of fruit from $0^{\circ} \mathrm{C}$ storage after $5 \mathrm{~d}$, and similar to that of non-stored fruit on day 7.

Weight loss of the nectarine fruit during $20^{\circ} \mathrm{C}$ shelf life is shown in Fig. 2. The least weight loss during shelf life was found in non stored fruit, and the highest in fruit stored at $0{ }^{\circ} \mathrm{C}$, due to the lower relative humidity in that storage room than in the $4{ }^{\circ} \mathrm{C}$ room.

Peel colour changes are shown in Table 1 for the three treatments. On the non-blush side the $L^{*}$ (lightness) value was higher, indicating a lighter peel, for fruits from $4^{\circ} \mathrm{C}$ storage than the other

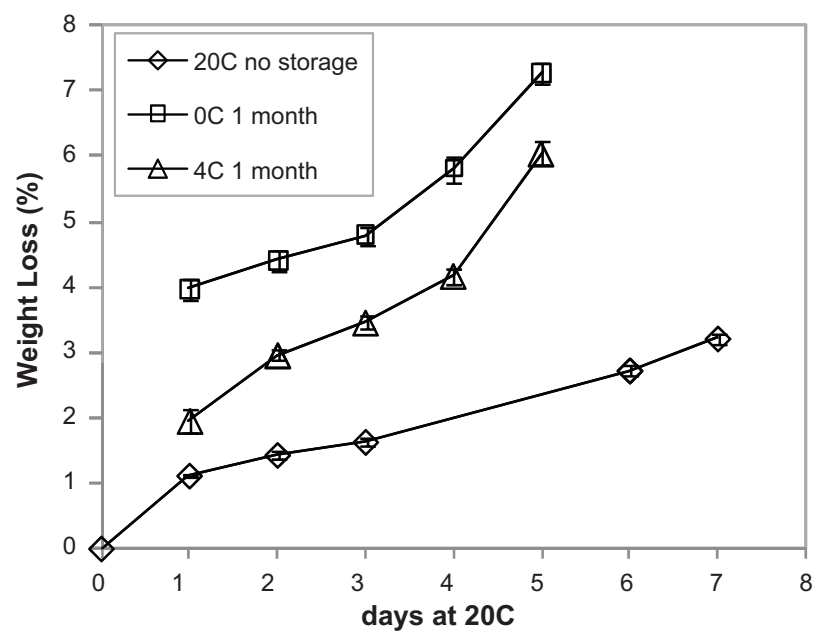

Fig. 2. Weight loss of nectarines held at $20^{\circ} \mathrm{C}$ without storage, or following $30 \mathrm{~d}$ storage at $4{ }^{\circ} \mathrm{C}$ or $0^{\circ} \mathrm{C}$. Standard error is indicated.

treatments. The $H^{\circ}$ value (hue angle) decreased during shelf life in all treatments, indicating a yellowing of the peel, while the $C^{*}$ (chroma) values increased. On the blush side all the measurement had large standard errors, probably because of great variation in the intensity of blush on the fruit. There were no large differences among the treatments, and none that were significant because of the great variation.

\subsection{Expressible juice}

Woolliness in nectarines, as a result of cold treatment, was measured by determining expressible juice. In expressible juice, the less juice that can be extracted, the greater the woolliness. The changes in expressible juice were quite different for fruit that were not stored or stored (Fig. 3). For fruit after cold storage $\left(0\right.$ and $\left.4{ }^{\circ} \mathrm{C}\right)$ a decrease was observed during shelf life, while for the non-stored fruit, an increase in expressible juice occurred as they decreased in firmness. For the first $3 \mathrm{~d}$ of shelf life, non-stored fruit had expressible juice of $45-50 \%$, while for the last two days of shelf life, this increased to close to $60 \%$. The stored fruit from both temperatures of storage began with $50 \%$ of expressible juice on the first day, and this decreased steadily to below $30 \%$ after $5 \mathrm{~d}$.

Table 1

Peel color $\left(L^{*}, C^{*}, H^{\circ}\right)$ of nectarine fruit during shelf life at $20^{\circ} \mathrm{C}$. Standard error is indicated.

\begin{tabular}{|c|c|c|c|c|c|c|c|c|c|}
\hline \multirow[t]{2}{*}{ Days at $20^{\circ} \mathrm{C}$} & \multicolumn{3}{|c|}{ Non-stored fruit } & \multicolumn{3}{|l|}{$0^{\circ} \mathrm{C}$} & \multicolumn{3}{|l|}{$4^{\circ} \mathrm{C}$ storage } \\
\hline & $L^{*}$ & $C^{*}$ & $H^{\circ}$ & $L^{*}$ & $C^{*}$ & $H^{\circ}$ & $L^{*}$ & $C^{*}$ & $H^{\circ}$ \\
\hline \multicolumn{10}{|c|}{ Non-blush side } \\
\hline 1 & $75.1 \pm 0.4$ & $53.8 \pm 0.4$ & $86.3 \pm 0.4$ & $75.8 \pm 0.3$ & $52.9 \pm 0.3$ & $85.5 \pm 0.6$ & $78.5 \pm 0.3$ & $54.5 \pm 0.4$ & $84.0 \pm 0.3$ \\
\hline 2 & $74.0 \pm 0.3$ & $53.7 \pm 0.4$ & $85.6 \pm 0.6$ & $76.2 \pm 0.4$ & $55.2 \pm 0.4$ & $82.6 \pm 0.5$ & $77.8 \pm 0.2$ & $54.7 \pm 0.4$ & $82.7 \pm 0.3$ \\
\hline 3 & $74.7 \pm 0.5$ & $54.7 \pm 0.5$ & $84.2 \pm 0.6$ & $76.6 \pm 0.3$ & $54.7 \pm 0.4$ & $81.2 \pm 0.4$ & $78.1 \pm 0.3$ & $55.0 \pm 0.4$ & $81.9 \pm 0.3$ \\
\hline 4 & & & & $76.1 \pm 0.4$ & $55.6 \pm 0.4$ & $80.4 \pm 0.5$ & $76.4 \pm 0.5$ & $56.0 \pm 0.6$ & $80.0 \pm 0.7$ \\
\hline 5 & & & & $74.9 \pm 0.5$ & $56.7 \pm 0.3$ & $79.6 \pm 0.5$ & $76.0 \pm 0.4$ & $56.8 \pm 0.3$ & $80.0 \pm 0.4$ \\
\hline 6 & $76.4 \pm 0.2$ & $57.0 \pm 0.4$ & $82.1 \pm 0.4$ & & & & & & \\
\hline 7 & $75.8 \pm 0.3$ & $57.4 \pm 0.4$ & $81.3 \pm 0.3$ & & & & & & \\
\hline \multicolumn{10}{|l|}{ Blush side } \\
\hline 1 & $42.8 \pm 1.5$ & $40.1 \pm 1.0$ & $35.5 \pm 2.2$ & $46.4 \pm 2.0$ & $39.9 \pm 1.4$ & $39.4 \pm 2.7$ & $47.5 \pm 1.7$ & $41.9 \pm 1.1$ & $38.8 \pm 2.1$ \\
\hline 2 & $44.0 \pm 1.4$ & $42.4 \pm 0.7$ & $37.1 \pm 1.9$ & $43.9 \pm 1.9$ & $41.0 \pm 1.2$ & $35.4 \pm 2.4$ & $43.7 \pm 1.5$ & $41.0 \pm 1.0$ & $33.7 \pm 1.8$ \\
\hline 3 & $44.2 \pm 1.6$ & $42.8 \pm 0.9$ & $37.0 \pm 2.1$ & $44.2 \pm 1.7$ & $41.9 \pm 1.2$ & $35.8 \pm 2.2$ & $45.5 \pm 1.8$ & $42.8 \pm 1.2$ & $35.7 \pm 2.1$ \\
\hline 4 & & & & $43.8 \pm 1.8$ & $41.8 \pm 1.2$ & $35.4 \pm 2.4$ & $43.1 \pm 1.8$ & $40.4 \pm 1.4$ & $33.3 \pm 2.3$ \\
\hline 5 & & & & $42.2 \pm 1.7$ & $40.6 \pm 1.3$ & $33.7 \pm 2.0$ & $42.5 \pm 1.1$ & $41.1 \pm 1.2$ & $32.9 \pm 1.5$ \\
\hline 6 & $43.1 \pm 1.5$ & $43.8 \pm 1.1$ & $34.0 \pm 1.8$ & & & & & & \\
\hline 7 & $44.4 \pm 1.6$ & $44.4 \pm 1.1$ & $35.8 \pm 1.9$ & & & & & & \\
\hline
\end{tabular}




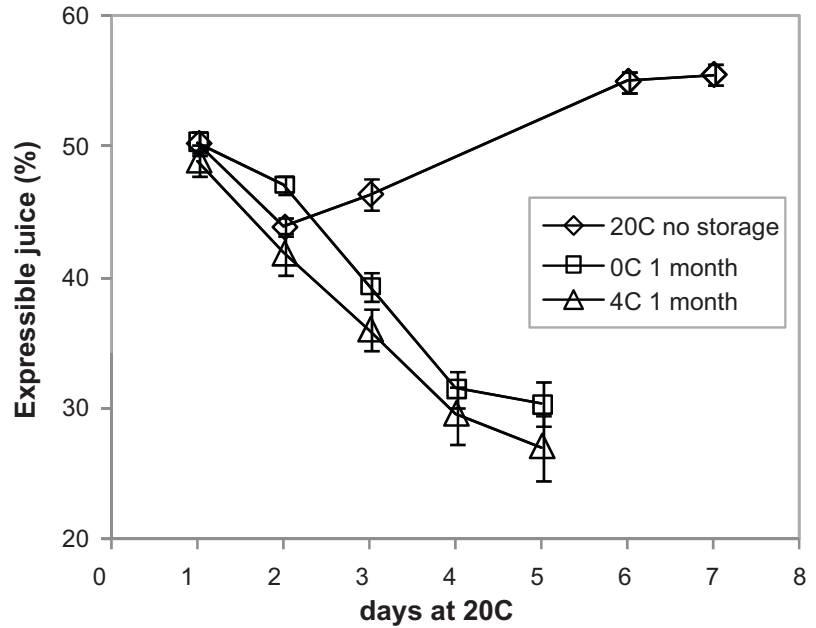

Fig. 3. Expressible juice of nectarines held at $20^{\circ} \mathrm{C}$ without storage, or following 30 d storage at $4{ }^{\circ} \mathrm{C}$ or $0{ }^{\circ} \mathrm{C}$. Standard error is indicated.

\subsection{Internal disorders of browning, bleeding and gel}

The development of changes in the fruit flesh was followed each day. During ripening without storage no disorders appeared (data not shown). However, fruit from both storage regimes had flesh disorders from the first day after storage, which increased continually during shelf life in fruit from $4{ }^{\circ} \mathrm{C}$ so that after $4 \mathrm{~d}$ there were no fruit with completely healthy flesh (Fig. 4). In fruit from $0{ }^{\circ} \mathrm{C}$ storage the increase in percentage of flesh disorders began after day 3 of shelf life, and by the end of shelf life was about $75 \%$ of the fruit. The time of appearance of the three flesh disorders, internal browning, internal bleeding and gel formation differed (Fig. 5). Gel formation and internal browning appeared on the second day of shelf life after $4{ }^{\circ} \mathrm{C}$ storage, and gel formation did not increase thereafter, while the internal browning became more intense on the last two days of shelf life. In contrast, bleeding was present immediately after removal from storage, and increased during the last two days at $20^{\circ} \mathrm{C}$. Fruit ripened after storage at $0^{\circ} \mathrm{C}$ did not develop any gel, while internal browning and bleeding increased mainly on the last two days of shelf life.

Fruit which had been classified at harvest using $\mu_{\mathrm{a}} 670$ as the 10 least and the 10 most mature fruit were examined as two groups for flesh disorders considering the severity indices. Internal browning appeared only in the more mature fruit from $0^{\circ} \mathrm{C}$, and was higher in more mature fruit from $4{ }^{\circ} \mathrm{C}$ than the less mature fruit (Fig. 5A). Gel formation was found only in fruit from $4{ }^{\circ} \mathrm{C}$ storage, and was higher

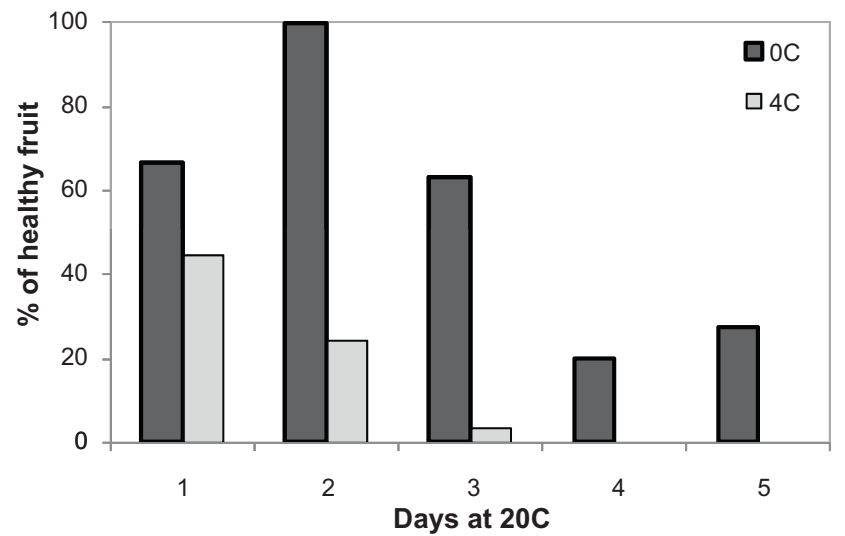

Fig. 4. The percentage of healthy fruit during shelf life at $20^{\circ} \mathrm{C}$ of fruits held for 30 d at $4^{\circ} \mathrm{C}$ or $0^{\circ} \mathrm{C}$
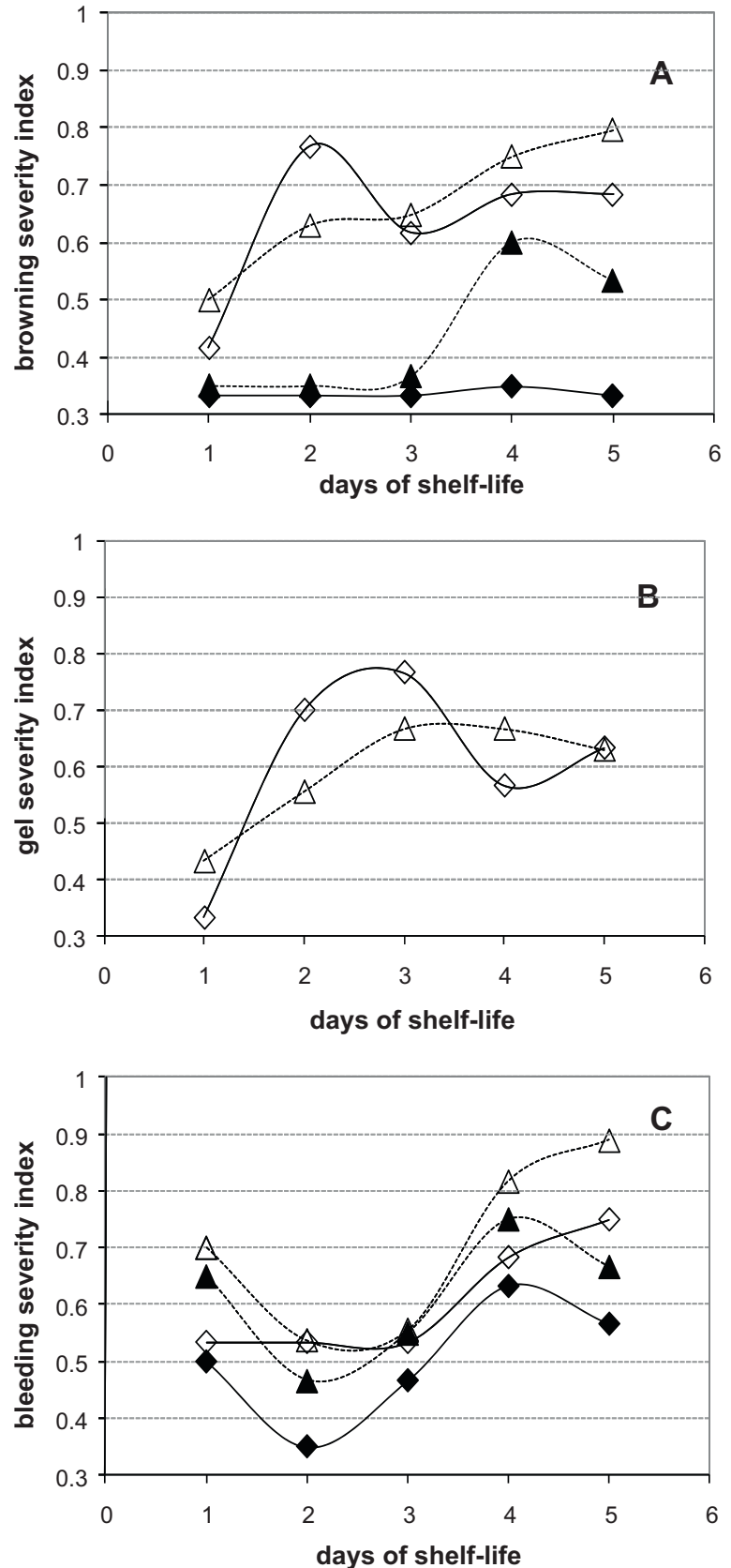

Fig. 5. Browning (A), gel (B), and bleeding (C) severity indices of the 10 most mature (more) and 10 least (less) mature fruit held for $5 \mathrm{~d}$ at $20^{\circ} \mathrm{C}$ after storage at $4{ }^{\circ} \mathrm{C}$ or $0{ }^{\circ} \mathrm{C}$. Severity index $=0.3$, all fruit without the defect (all scored 1 ), severity index $=1$, all fruit having the defect scored 3.

at the beginning in the less mature fruit, but similar at the end of shelf life in both maturity groups (Fig. 5B). The bleeding severity index was similar in fruit from both storage temperatures, but in both cases was higher in the more mature fruit (Fig. 5C).

\subsection{Changes in $\mu_{a} 670 \mathrm{~nm}$ and $\mu_{a} 780 \mathrm{~nm}$}

When the whole data set for the $5 \mathrm{~d}$ of each treatment was examined for the TRS measurements, it was found that the scattering coefficient $\mu^{\prime}{ }_{s} 670$ at harvest (mean \pm standard error, $18.12 \pm 0.19 \mathrm{~cm}^{-1}$ ) was significantly lower than values after cold 

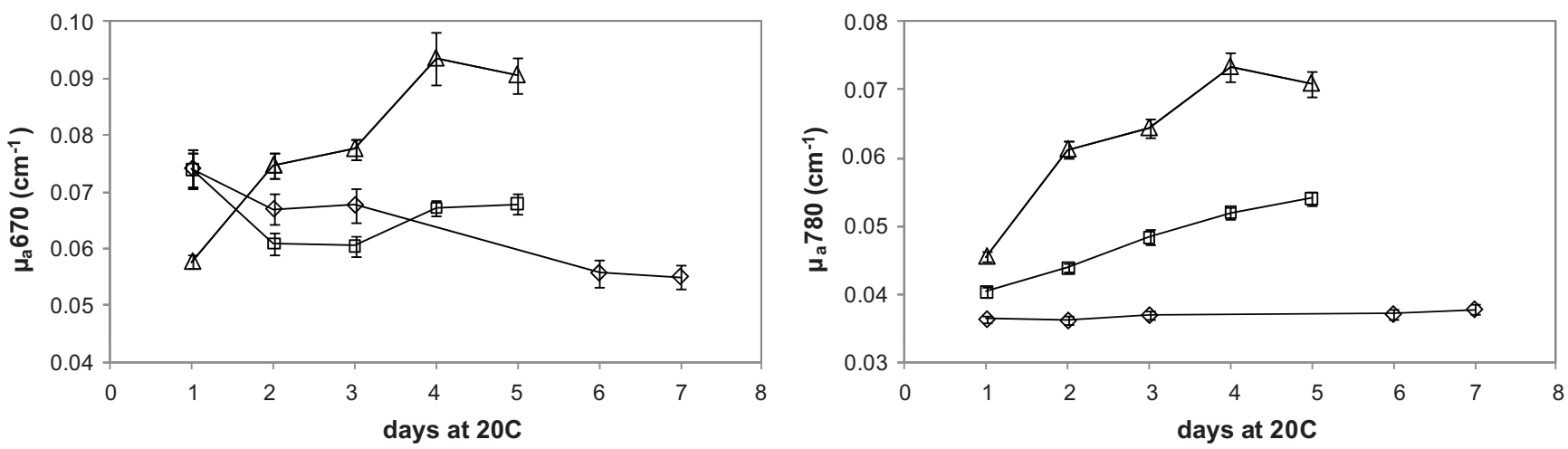

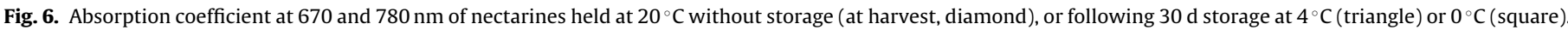
Diamond, fruit after harvest; square, fruit from $0{ }^{\circ} \mathrm{C}$ storage; triangle, fruit from $4{ }^{\circ} \mathrm{C}$ storage. Standard error is indicated.

storage $\left(19.39 \pm 0.21 \mathrm{~cm}^{-1}\right)$, whereas $\mu^{\prime}{ }_{s} 780$ did not significantly differ among treatments $\left(17.63 \pm 0.16 \mathrm{~cm}^{-1}\right)$ (data not shown). However the absorption coefficient at both wavelengths did differentiate among the treatments: the fruit that were stored at $4{ }^{\circ} \mathrm{C}$ had higher $\mu_{\mathrm{a}} 670$ values $\left(0.079 \pm 0.002 \mathrm{~cm}^{-1}\right)$ than fruit without storage $\left(0.067 \pm 0.001 \mathrm{~cm}^{-1}\right)$ or after $0^{\circ} \mathrm{C}$ storage $\left(0.066 \pm 0.001 \mathrm{~cm}^{-1}\right)$ (Fig. 6). The fruit from both $0^{\circ} \mathrm{C}$ and $4{ }^{\circ} \mathrm{C}$ storage had higher $\mu_{\mathrm{a}} 780$ values $\left(0^{\circ} \mathrm{C}, 0.048 \pm 0.0006 \mathrm{~cm}^{-1} ; 4^{\circ} \mathrm{C}, 0.063 \pm 0.001 \mathrm{~cm}^{-1}\right)$ than fruit after harvest $\left(0.037 \pm 0.0003 \mathrm{~cm}^{-1}\right)$.

When each treatment was examined daily during shelf life the kinetics were quite different at the two wavelengths, and among the treatments (Fig. 6). At $\mu_{\mathrm{a}} 670$ fruit after harvest decreased in absorption as they ripened, as would be expected if the chlorophyll disappears during shelf life. Fruit after $0^{\circ} \mathrm{C}$ began to decrease in $\mu_{\mathrm{a}} 670$ for the first $3 \mathrm{~d}$ at $20^{\circ} \mathrm{C}$, and then this was reversed during the last $2 \mathrm{~d}$ of shelf life. Concomitantly, fruit from $4{ }^{\circ} \mathrm{C}$ storage increased in $\mu_{\mathrm{a}} 670$ as shelf life was extended. The fruit without storage did not change in $\mu_{\mathrm{a}} 780$ during $7 \mathrm{~d}$ at $20^{\circ} \mathrm{C}$. However, stored fruit, from either $0^{\circ} \mathrm{C}$ or $4^{\circ} \mathrm{C}$, increased in absorption, with greater increases occurring after $4^{\circ} \mathrm{C}$ storage.

Considering the seven categories of pulp defects (Fig. 7), it was found that $\mu_{\mathrm{a}} 780$ discriminated healthy fruit $(\mathrm{H})$ from those affected by defects. In addition, fruit with bleeding (BL) could be discriminated from those affected by browning (BR, BR+G, $\mathrm{BR}+\mathrm{BL}+\mathrm{G})$. The $\mu_{\mathrm{a}} 670$ was significantly lower in healthy and $\mathrm{BL}$ fruit, compared to values found in fruit with $B R+B L, B R+G$ and $\mathrm{BR}+\mathrm{BL}+\mathrm{G}$.

PCA based on the optical properties measured during shelf life after storage at 0 and $4{ }^{\circ} \mathrm{C}\left(\mu_{\mathrm{a}} 670, \mu_{\mathrm{a}} 780, \mu^{\prime}{ }_{\mathrm{s}} 670\right.$ and $\left.\mu^{\prime}{ }_{\mathrm{s}} 780\right)$ and the scores of each fruit regarding bleeding, browning and gel

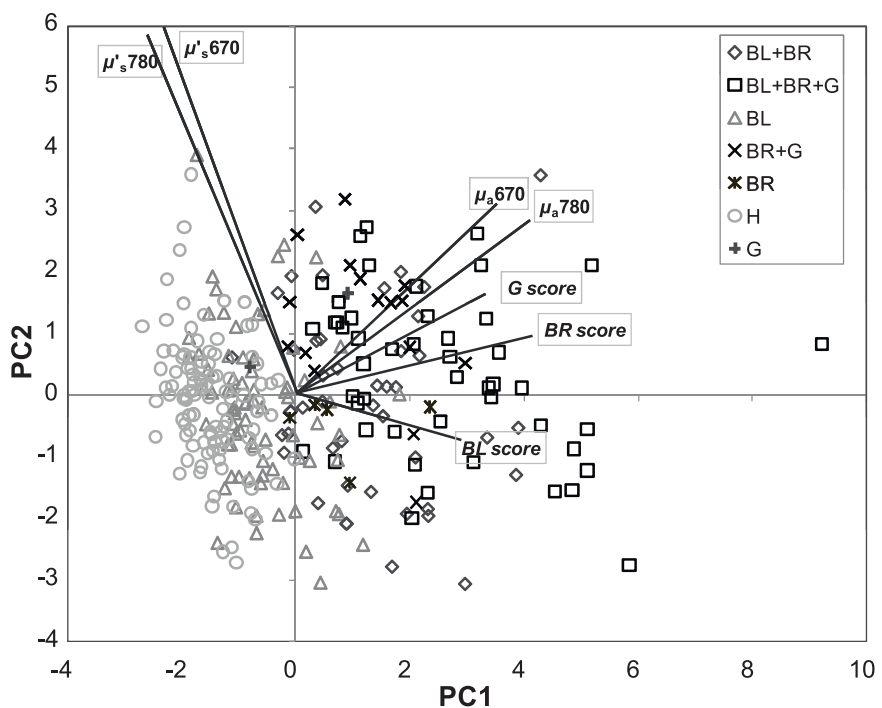

Fig. 8. PCA of optical properties at 670 and $780 \mathrm{~nm}$ and scores of defects. Biplot of PC1 vs PC2 showing the loadings of variables and the scores of all fruits from shelf life of nectarines stored for $30 \mathrm{~d}$ at $4{ }^{\circ} \mathrm{C}$ or $0{ }^{\circ} \mathrm{C}$. Symbols refer to the defect categories $\mathrm{H}$, healthy; $\mathrm{BR}$, internal browning; $\mathrm{BL}$, internal bleeding; $\mathrm{G}$, gel breakdown; $\mathrm{BR}+\mathrm{BL}$, $B R+G, B R+B L+G$, combinations of defects.

allowed the selection of two principal components (PC) which explained $70.60 \%$ of total variation (Fig. 8). In PC1 (47.53\% of total variance) browning score (BR) and gel score (G) were positively related to $\mu_{\mathrm{a}} 670$ and $\mu_{\mathrm{a}} 780$, whereas in PC2 (23.07\% of total vari-
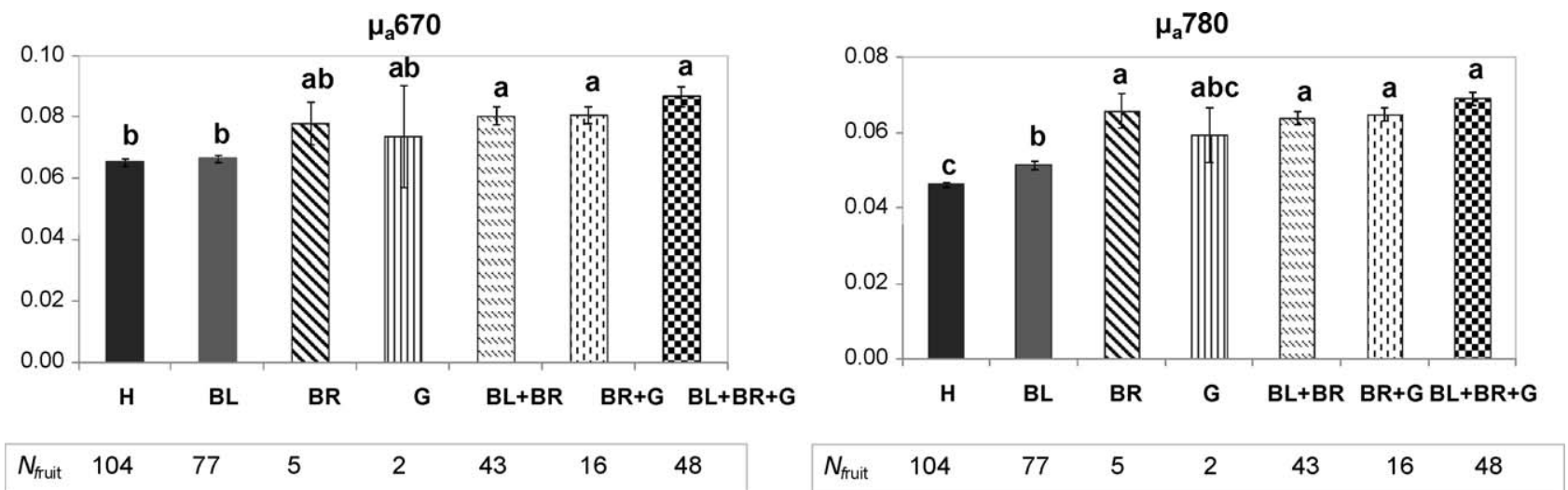

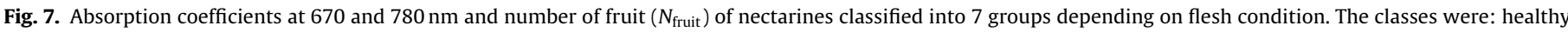

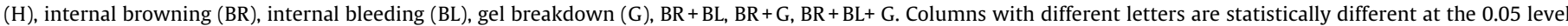
according to Tukey's test. Standard error is indicated. 
Table 2

Correlation coefficients of absorption $\left(\mu_{\mathrm{a}}\right)$ and scattering $\left(\mu_{\mathrm{s}}^{\prime}\right)$ coefficients at 670 and $780 \mathrm{~nm}$ measured during shelf-life at $20^{\circ} \mathrm{C}$ with expressible juice (harvest $(\mathrm{H})$, $n=148$; after storage at $4{ }^{\circ} \mathrm{C}(\mathrm{ST} 4), n=145$; after storage at $0{ }^{\circ} \mathrm{C}(\mathrm{ST} 0), n=148$; pooled treatments, $n=443$ ).

\begin{tabular}{lllll}
\hline Treatments & $\mu_{\mathrm{a}} 670$ & $\mu_{\mathrm{a}} 780$ & $\mu_{\mathrm{s}}^{\prime} 670$ & $\mu_{\mathrm{s}}^{\prime} 780$ \\
\hline H & $-0.459^{* * *}$ & $-0.079^{\mathrm{ns}}$ & $-0.043^{\mathrm{ns}}$ & $-0.392^{* * *}$ \\
ST0 & $-0.014^{\mathrm{ns}}$ & $-0.618^{* * *}$ & $+0.049^{\mathrm{ns}}$ & $+0.316^{* * *}$ \\
ST4 & $-0.396^{* * *}$ & $-0.438^{* * *}$ & $+0.062^{\mathrm{ns}}$ & $+0.092^{\mathrm{ns}}$ \\
Pooled & $-0.364^{* * *}$ & $-0.559^{* * *}$ & $-0.049^{\mathrm{ns}}$ & $+0.078^{\mathrm{ns}}$ \\
\hline
\end{tabular}

S*** Significance of $r: p \leq 0.001$.

ance) $\mu^{\prime}{ }_{s} 670$ and $\mu^{\prime}{ }_{s} 780$ were selected. Both functions were able to distinguish fruit belonging to the various categories of pulp defects. PC1 distinguished healthy $(\mathrm{H})$ fruit from those affected by pulp defects, with $\mathrm{H}$ category fruit having the lowest mean score (mean \pm standard error, $-1.48 \pm 0.05$ ); BL category differed from $\mathrm{BR}+\mathrm{G}, \mathrm{BL}+\mathrm{BR}$ and $\mathrm{BL}+\mathrm{BR}+\mathrm{G}$ ones, having BL category a negative score $(-0.61 \pm 0.09)$ and the others positive scores, that is: $\mathrm{BR}+\mathrm{G}, 1.21 \pm 0.24 ; \mathrm{BL}+\mathrm{BR}, 1.27 \pm 0.19$ and $\mathrm{BL}+\mathrm{BR}+\mathrm{G}, 2.56 \pm 0.27$. $\mathrm{PC} 2$ was able to distinguish $\mathrm{BR}+\mathrm{G}$ category $(1.15 \pm 0.30)$ from $\mathrm{H}$ $(-0.11 \pm 0.10), \mathrm{BL}(-0.27 \pm 0.15)$ and $\mathrm{BL}+\mathrm{BR}(-0.05 \pm 0.23)$. In addition, all the categories having gel, i.e. $G, B R+G$ and $B L+B R+G$, showed positive scores, in contrast with the other categories, all having negative mean scores.

From the study of the correlations between expressible juice and optical properties, a different scenario was found for each treatment (Table 2). At harvest there were significant negative correlations with $\mu_{\mathrm{a}} 670$ and $\mu_{\mathrm{s}}^{\prime} 780$; after storage at $0{ }^{\circ} \mathrm{C}$, a negative correlation was found with $\mu_{\mathrm{a}} 780$ and a positive one with $\mu_{\mathrm{s}}^{\prime} 780$. On the other hand, after storage at $4{ }^{\circ} \mathrm{C}$ significant negative correlations were found for $\mu_{\mathrm{a}} 670$ and $\mu_{\mathrm{a}} 780$.

\subsection{Canonical discriminant analysis}

Canonical discriminant analysis based on seven selected attributes: $\mu_{\mathrm{a}} 780, \mu_{\mathrm{a}} 670$, weight loss, firmness, expressible juice, $L^{*}$ of the non-blush side and $C^{*}$ of the blush side of the fruit, indicated that the Canonical function 1 (Can1) accounted for $71.5 \%$ of the variation in the 7 variables of the three treatments during the last two days of shelf life, and the remaining $28.5 \%$ variation was accounted for by Canonical function 2 (Can2). In other words, two Canonical functions accounted for almost all the variation.

Can 1 separated fruit without cold storage $\left(20^{\circ} \mathrm{C}\right.$ fruit $)$ from cool stored fruit and Can2 separated fruit cool stored at $4{ }^{\circ} \mathrm{C}$ from those cool stored at $0^{\circ} \mathrm{C}$ (Fig. 9). Total-sample standardized canonical coefficients (an indication of relative importance of the selected attributes for discriminating) indicated that Can1 separated fruit based predominantly on the contrast between $\mu_{\mathrm{a}} 780$ and $\mu_{\mathrm{a}} 670$, followed by weight loss, expressible juice and firmness. Fruit without cold storage had low $\mu_{\mathrm{a}} 780$, weight loss, and firmness, but high $\mu_{\mathrm{a}} 670$ and expressible juice compared with cool stored fruit. Can2 separated fruit based predominantly on $\mu_{\mathrm{a}} 780$, followed by firmness, weight loss and expressible juice. Fruit cool stored at $4{ }^{\circ} \mathrm{C}$ had high $\mu_{\mathrm{a}} 780$ and expressible juice, but low weight loss and firmness compared with fruit cool stored at $0{ }^{\circ} \mathrm{C}$. The contribution of the last two variables, $L^{*}$ and Chroma, were very small for both Can 1 and Can2.

\section{Discussion}

Sorting nectarines at harvest into maturity levels using TRS measurement of $\mu_{\mathrm{a}} 670$ was shown to be an effective way of predicting their softening kinetics. Two models were developed, one for the decrease of $\mu_{\mathrm{a}}$ (Tijskens et al., 2006) and one for fruit softening (firmness) (Tijskens et al., 2007), based on the assumption that

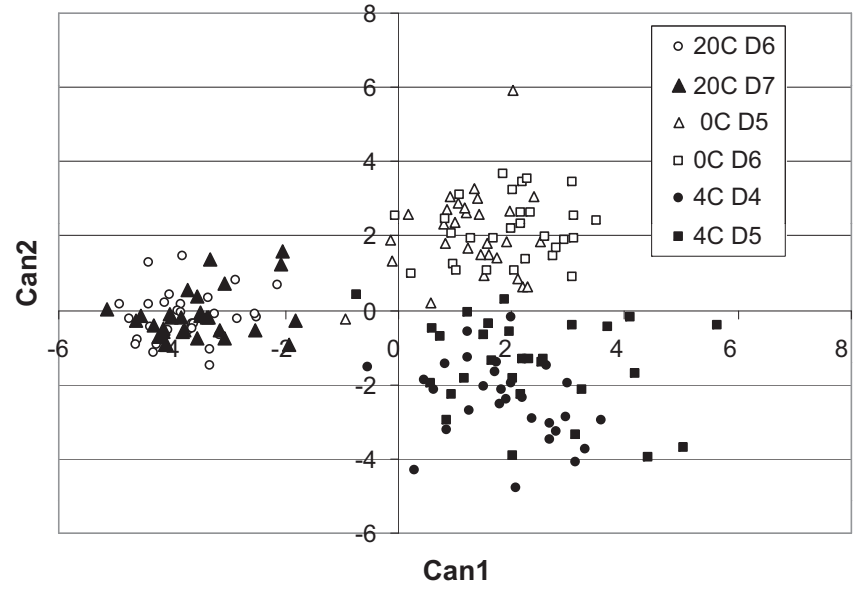

Fig. 9. Canonical discriminant analysis of all fruit from the last $2 \mathrm{~d}$ of shelf life of nectarines without storage (day 6 and 7), and nectarines stored for $30 \mathrm{~d}$ at $4{ }^{\circ} \mathrm{C}$ or $0{ }^{\circ} \mathrm{C}$ (day 4 and 5 ).

these two processes are highly coupled or synchronized, so that the biological shift factor for $\mu_{\mathrm{a}}$ and the one for firmness can be mutually exchanged by a linear relation. The model thus included the variations in maturity at harvest of the individual fruit. The absorption coefficient at $670 \mathrm{~nm}$ measured at harvest was used in the model to describe the maturity at harvest and the future behavior in terms of firmness, e.g. to predict the rate of softening and thus the duration of shelf life (Rizzolo et al., 2009). The TRS measurement coupled with the biological shift factor theory was successfully applied in an export trial from Italy to The Netherlands, simulating on a small scale the fruit supply chain from the packing-house to the consumer (Eccher Zerbini et al., 2009).

In the current study $\mu_{\mathrm{a}} 670$ was used to group the nectarines into replicates that contained the whole variation of the maturity in each replicate. This allowed an investigation of the storage disorders to be focused on the interaction of storage temperature and fruit maturity. The results indicated that the more mature fruit were more susceptible to internal disorders than the less mature fruit. However, the spread of maturities in this study was much less broad than in previous ones. The distribution of $\mu_{\mathrm{a}}$ measured at harvest showed a range much smaller $\left(0.15-0.03 \mathrm{~cm}^{-1}\right)$ than that found in the early cv. Spring Bright $\left(0.35-0.03 \mathrm{~cm}^{-1}\right)$ (Tijskens et al., 2006).

In the present study, storage disorders developed during ripening following storage at either 0 or $4^{\circ} \mathrm{C}$. However, there were some differences in the type of storage disorders and their intensity in fruit from the two storage regimes, with no gel development in fruit stored at $0^{\circ} \mathrm{C}$ and very little internal browning. Fruit at $4{ }^{\circ} \mathrm{C}$ had both of these disorders. Bleeding in the flesh was also lower in fruit from $0{ }^{\circ} \mathrm{C}$ than from $4{ }^{\circ} \mathrm{C}$. The development of internal disorders, such as internal browning or bleeding significantly influenced both the absorption coefficients, but mainly $\mu_{\mathrm{a}} 780$. In fact, in agreement with previous results on nectarines, $\mu_{\mathrm{a}} 670$ decreased as fruit ripening increased (Tijskens et al., 2006): in non stored fruit the decrease was till the end of shelf life, and in those stored at $0{ }^{\circ} \mathrm{C}$ till day 3 , when there was an increase in bleeding and internal browning for this treatment. In contrast, in fruit stored at $4{ }^{\circ} \mathrm{C}$, the appearance of internal browning already at day 1 of shelf life did not allow us to follow the decrease of $\mu_{\mathrm{a}} 670$ in shelf life due to the chlorophylla breakdown, but instead caused an increase in both $\mu_{\mathrm{a}} 670$ and $\mu_{\mathrm{a}} 780$. The fact that the increase in $\mu_{\mathrm{a}} 780$ in shelf life observed in nectarines could be due to the development of internal browning is in agreement with what was found in Granny Smith apples, where $\mu_{\mathrm{a}} 750$ increased and $\mu_{\mathrm{s}}^{\prime} 750$ decreased with the development of internal browning (Vanoli et al., 2010). As for gel, it could be assumed that it would influence the absorption and scattering 
coefficients at $780 \mathrm{~nm}$, similarly to what found for watercore in Fuji apples (Vanoli et al., 2010), where healthy 'Fuji' pulp was characterized by lower $\mu_{\mathrm{a}} 790$ and higher $\mu^{\prime}{ }_{\mathrm{s}} 790$ than tissue affected by watercore. In Morsiani 90 nectarines, a clear relationship between $\mu^{\prime}{ }_{s} 780$ and gel was not found, probably due to the very low number of fruit grouped (only 2 ) in the $G$ category. In most cases gel was accompanied by either browning $(B R+G)$, or by browning and bleeding $(\mathrm{BR}+\mathrm{BL}+\mathrm{G})$. However, $\mathrm{PCA}$ results suggest that gel breakdown either alone $(G)$ or associated with browning $(B R+G)$ or with browning and bleeding $(B L+B R+G)$ could be related to the reduced scattering coefficients at 670 and $780 \mathrm{~nm}$.

Morsiani 90 is a freestone late-season variety with non-melting flesh. According to Brovelli et al. (1998) flesh woolliness as a result of chilling exposure in non-melting peaches is not as severe as is the case with melting fleshed peaches. In Morsiani 90 nectarines, the visual evaluation of symptoms of woolliness, defined as a coarse texture associated to a dry appearance, was difficult probably due to the very slight symptoms, which resulted in visible juice on the cut surface of the fruit, and with very slight pulp disruption and pastiness. However, the expressible juice trends of stored nectarines at both temperatures indicate a development of woolliness whatever the storage temperature.

It is known that fruit softening is accompanied with changes in the tissue density, weakening of cell-cell adhesion and changes in cell wall polymers, all of which may affect light scattering. Soft fruit have broader scattering profiles than firm fruit (Peng and Lu, 2004; Qin and Lu, 2008). Woolliness development causes changes to the cell wall polymers and decreases the amount of apoplastic liquid in the tissue (Lurie et al., 2000, 2003). These alterations would be expected to change the scattering profiles in a different way than normal softening.

Our results indicate that optical properties correlated to expressible juice differently depending on the treatment. At harvest, when no $\mathrm{CI}$ occurred and expressible juice increased with shelf life, there were negative relationships with $\mu_{\mathrm{a}} 670$, which decreases with ripening due to chlorophyll-a breakdown (Tijskens et al., 2006), and with $\mu_{\text {s }}^{\prime} 780$, which decreases with fruit softening similarly to what was found by Qin and Lu (2008). After storage at $0{ }^{\circ} \mathrm{C}$, by plotting expressible juice against $\mu_{\mathrm{a}} 780$, it was found that higher values of $\mu_{\mathrm{a}} 780$ were found in fruit having expressible juice lower than 30\% and bleeding and browning scores greater than 2 (data not shown). Nectarines with this type of CI were found at the end of shelf life, and more advanced in ripeness. These fruit had lower values of $\mu^{\prime}{ }_{s} 780$, and a positive correlation between expressible juice and $\mu^{\prime}{ }_{\mathrm{s}} 780$. After storage at $4{ }^{\circ} \mathrm{C}$, for $\mu_{\mathrm{a}} 670>0.1 \mathrm{~cm}^{-1}$ and $\mu_{\mathrm{a}} 780>0.080 \mathrm{~cm}^{-1}$ only browned fruit with expressible juice less than $30 \%$ could be found. So, when there was a less severe incidence of $\mathrm{CI}$ symptoms, as in the case of fruit stored at $0^{\circ} \mathrm{C}$, there was a correlation, even if weak, between woolliness as measured by expressible juice and $\mu^{\prime}{ }_{s} 780$. On the other hand, when there was a severe incidence of $\mathrm{CI}$ symptoms, as in fruit stored at $4^{\circ} \mathrm{C}, \mu^{\prime}$ s did not show any correlation with woolliness development, due to the influence of the high absorption values related to internal browning which could have affected the estimation of scattering properties.

Canonical discriminant analysis was able to separate the fruit from all three treatments on the last $2 \mathrm{~d}$ of shelf life. These were the days when differences in flesh quality were the most apparent. Of the seven attributes found to be relevant, two of them relating to peel colour contributed only in a minor way to the analysis and could be ignored. The other five were $\mu_{\mathrm{a}}$ at both wavelengths, expressible juice, firmness and weight loss. The separation of fruit from $0^{\circ} \mathrm{C}$ or $4{ }^{\circ} \mathrm{C}$ was mainly due to differences in $\mu_{\mathrm{a}} 780$, weight loss and firmness. Absorption at $780 \mathrm{~nm}$ was $0.02 \mathrm{~cm}^{-1}$ higher in fruit from $4{ }^{\circ} \mathrm{C}$ storage compared to $0^{\circ} \mathrm{C}$, weight loss was less and fruit were softer at $4{ }^{\circ} \mathrm{C}$ than at $0^{\circ} \mathrm{C}$.
This is the first study which shows the ability of an optical non-destructive technique, such as TRS, to determine nectarine storage disorders. Both wavelengths, 670 and $780 \mathrm{~nm}$ were able to differentiate between healthy and fruit with either woolliness, internal browning or internal bleeding. The major differences have been found for the absorption coefficients and were greater at 780 than at $670 \mathrm{~nm}$. The light scattering at $670 \mathrm{~nm}$ did not differentiate between healthy and disordered tissue, whereas $\mu_{\text {s }}^{\prime} 780$ could differentiate between fruit with high expressible juice and those having low values of expressible juice. Future work will try to increase the sensitivity of the measurements in order to detect differences between healthy and disordered tissue at an earlier time in the ripening process.

\section{Acknowledgements}

We thank the Cooperativa Intesa, Faenza (Ravenna Province) for supplying the nectarines. We thank grant agreement no. 228334 LASERLAB-EUROPE II (EU FP7-INFRASTRUCTURES-2008-1) for a fellowship to S. Lurie.

\section{References}

Bianchi, G., Rizzolo, A., Eccher Zerbini, P., Vanoli, M., 2004. QDA and GCO analysis of total aroma extracts from 'Spring Bright' nectarines sorted by TRS. In: A Sense of Identity. European Conference on Sensory Science of Food and Beverages, Firenze (Italy), September 26-29, Abstract n. P77.

Brovelli, E.A., Brecht, J.K., Sherman, W.B., Sims, C.A., 1998. Quality of fresh market melting- and nonmelting flesh peach genotypes as affected by postharvest chilling. J. Food Sci. 63, 730-733.

Bruhn, C.M., Feldman, N., Garlitz, C., Hardwood, J., Ivan, E., Marshall, M., Riley, A., Thurber, D., Williamson, E., 1991. Consumer perceptions of quality: apricots, cantaloupes, peaches, pears, strawberries, and tomatoes. J. Food Qual. 14, 187-195.

Crisosto, C.H., Mitchell, F.G., Johnson, R.S., 1995. Factors in fresh market stone fruit quality. Postharvest News Inf. 5, 17N-21N.

Crisosto, C.H., Mitchell, F.G., Ju, Z., 1999. Susceptibility to chilling injury of peach, nectarine, and plum cultivars grown in California. HortScience 34, 1116-1118.

Cruz-Castillo, J.G., Ganeshanandam, S., MacKay, B.R., Lawes, G.S., Lawoko, C.R.O., Woolley, D.J., 1994. Applications of canonical discriminant analysis in horticultural research. HortScience 29, 1115-1119.

Cubeddu, R., D’Andrea, C., Pifferi, A., Taroni, P., Torricelli, A., Valentini, G., Dover, C., Johnson, D., Ruiz-Altisent, M., Valero, C., 2001. Non-destructive quantification of chemical and physical properties of fruits by time-resolved reflectance spectroscopy in the wavelength range $650-1000 \mathrm{~nm}$. Appl. Opt. 40, 538543.

Eccher Zerbini, P., Grassi, M., Fibiani, M., Rizzolo, A., Biscotti, G., Pifferi, A., Torricelli, A., Cubeddu, R., 2003. Selection of 'Springbright' nectarines by time-resolved reflectance spectroscopy (TRS) to predict fruit quality in the marketing chain. Acta Hortic. 604, 171-177.

Eccher Zerbini, P., Vanoli, M., Grassi, M., Rizzolo, A., Fibiani, M., Cubeddu, R., Pifferi, A., Spinelli, L., Torricelli, A., 2006. A model for the softening of nectarines based on sorting fruit at harvest by time-resolved reflectance spectroscopy. Postharvest Biol. Technol. 39, 223-232.

Eccher Zerbini, P., Vanoli, M., Rizzolo, A., Jacob, S., Torricelli, A., Spinelli, L., Schouten, R.E., 2009. Time-resolved reflectance spectroscopy as a management tool in the fruit supply chain: an export trial with nectarines. Biosyst. Eng. 102, 360363.

Harding, P.L., Haller, M.H., 1934. Peach storage with special reference to breakdown. Proc. Am. Soc. Hortic. Sci. 32, 160-163.

Jacob, S., Vanoli, M., Grassi, M., Rizzolo, A., Eccher Zerbini, P., Cubeddu, R., Pifferi, A., Spinelli, L., Torricelli, A., 2006. Changes in sugar and acid composition of 'Ambra' nectarines during shelf life in relation to non-destructive assessment of maturity by time-resolved reflectance spectroscopy. J. Fruit Ornam. Plant Res. $14,183-194$.

Lill, R.E., van der Mespel, G.J., 1988. A method for measuring the juice content of mealy nectarines. Sci. Hortic. 36, 267-271.

Lurie, S., Crisosto, C.H., 2005. Chilling injury in peach and nectarine. Postharvest Biol. Technol. 37, 195-208.

Lurie, S., Zhou, H.W., Sonego, L., Khalchitski, A., Ben Arie, R., Lers, A., 2000. Cell wall enzymes and cell wall changes in nectarines (Prunus persica): mRNA abundance, enzyme activity and changes in pectic and neutral polymers during ripening and woolly fruit. J. Am. Soc. Hortic. Sci. 125, 630-637.

Lurie, S., Zhou, H.W., Lers, A., Sonego, L., Alexandrov, S., Shomer, I., 2003. Study of pectin esterase and changes in pectin methylation during normal and abnormal peach ripening. Physiol. Plantarum 119, 287-294.

Peace, C.P., Ahmad, R., Gradziel, T.M., Dandekar, A.M., Crisosto, C.H., 2004. The use of molecular genetics to improve peach and nectarine post-storage quality. Acta Hortic. 682, 403-415. 
Peng, Y., Lu, R., 2004. A liquid crystal tunable filter based multispectral imaging system for prediction of apple fruit firmness. Proc. SPIE Int. Soc. Opt. Eng. 5587, 91-100.

Qin, J., Lu, R., 2008. Measurement of the optical properties of fruits and vegetables using spatially resolved hyperspectral diffuse reflectance imaging technique. Postharvest Biol. Technol. 49, 355-365.

Rizzolo, A., Vanoli, M., Eccher Zerbini, P., Jacob, S., Torricelli, A., Spinelli, L., Schouten, R.E., Tijskens, L.M.M., 2009. Prediction ability of firmness decay models of nectarines based on the biological shift factor measured by time-resolved reflectance spectroscopy. Postharvest Biol. Technol. 54, 131-140.

Tijskens, L.M.M., Eccher Zerbini, P., Vanoli, M., Jacob, S., Grassi, M., 2006. Effects of maturity on chlorophyll-related absorption in nectarines, measured by nondestructive time-resolved reflectance spectroscopy. Int. J. Postharvest Technol. Innov. 1, 178-188.

Tijskens, L.M.M., Eccher Zerbini, P., Schouten, R.E., Vanoli, M., Jacob, S., Grassi, M.,
Cubeddu, R., Spinelli, L., Torricelli, A., 2007. Assessing harvest maturity in nectarines. Postharvest Biol. Technol. 43, 204-213.

Torricelli, A., Spinelli, L., Contini, D., Vanoli, M., Rizzolo, A., Eccher Zerbini, P., 2008. Time-resolved reflectance spectroscopy for non-destructive assessment of food quality. Sensing Instrum. Food Qual. Saf. 2, 82-89.

Vanoli, M., Rizzolo, A., Grassi, M., Zanella, A., Torricelli, A., Spinelli, L., Eccher Zerbini, P., 2007. Relationship between scattering properties as measured by timeresolved reflectance spectroscopy and quality in apple fruit. In: Proceedings of the 3rd International Symposium CIGR section VI, Food and Agricultural Products: Processing and Innovation, Naples, Italy, CD-ROM.

Vanoli, M., Rizzolo, A., Eccher Zerbini, P., Spinelli, L., Torricelli, A., 2010. Nondestructive detection of internal defects in apple fruit by time-resolved reflectance spectroscopy. International Conference "Environmentally friendly and safe technologies for quality of fruits and vegetables", Faro (Portugal), 14-16 January, 2009, p. 10 (Book of Abstracts). 